\title{
Influence of Location on Quality Attributes and Storage Performance of Sweet Orange (Blood Red)
}

\section{Aurang Zeb ${ }^{1}$, Abdur Rab ${ }^{1}$, Shujaat Ali ${ }^{1,2 *}$, Ijaz Hussain ${ }^{2}$, Shah Masaud Khan ${ }^{2}$, Israr Ahmad ${ }^{1}$, Bilal Pervaiz Khan $^{1}$, Shakila Umer ${ }^{3}$ and Muhammad Abbas ${ }^{1}$}

${ }^{1}$ Department of Horticulture Faculty of Crop Production Sciences, The University of Agriculture Peshawar, Khyber Pakbtunkbwa, Pakistan; ${ }^{2}$ Department of Agricultural Sciences, University of Haripur, Khyber Pakbtunkbwa, Pakistan; ${ }^{3}$ Department of Biotechnology and Genetics Engineering, Hazara University, Mansehra, Khyber Pakhtunkhwa, Pakistan.

\begin{abstract}
The lab experiment was conducted to evaluate the influence of location on quality attributes and storage performance of Sweet orange (Blood red). The Sweet oranges were collected from four different locations i.e. location-1 (Torwarsak, Buner), location-2 (Rabat, Lower Dir), location-3 (Wartair, Malakand) and location-4 (Palai, Malakand), which were stored in three replications at room condition for 48 days and Complete Randomized Design was used during the post-harvest experiment. Data were recorded on fruit juice $\mathrm{pH} \%$, titratable acidity, percent juice content, Rind thickness, Rind weight loss, at 12 days intervals. The fruit juice $\mathrm{pH}$ showed an increasing trend from the start to the end of storage. While the juice content decreased with storage intervals. The maximum titratable acidity (1.97) was documented from Palai (Malakand) in freshly harvested fruits after 48 days of storage. The minimum rind thickness $(0.66 \mathrm{~mm})$ and the highest rind weight loss percentage $(41.42 \%)$ was recorded after 48 days of storage. It is concluded that Sweet orange fruits from different locations can be best stored at room temperature $\left(20 \pm 1{ }^{\circ} \mathrm{C}\right.$ with a relative humidity of 45-50\%).

Received | November 14, 2020; Accepted | December 31, 2020; Published | June 02, 2021

*Correspondence | Shujaat Ali, Department of Horticulture Faculty of Crop Production Sciences, The University of Agriculture Peshawar, Khyber Pakhtunkhwa, Pakistan; Email: shujat.swati@gmail.com

Citation $\mid$ Zeb, A., A. Rab, S. Ali, I. Hussain, S.M. Khan², I. Ahmad, B.P. Khan, S. Umer and M. Abbas. 2021. Influence of location on quality attributes and storage performance of sweet orange (Blood Red). Pakistan Journal of Agricultural Research, 34(2): 438-443.

DOI | http://dx.doi.org/10.17582/journal.pjar/2021/34.2.438.443

Keywords | Blood red, Locations, Quality attributes, Relative humidity, Room temperature, Storage days
\end{abstract}

\section{Introduction}

$\mathrm{C}$ itrus sinensis L. commonly known as sweet orange, part of the citrus group, belongs to Rutaceae family. Citrus Sinensis is originated from northern China and is adoptive to tropical, subtropical and mild temperate climates (Piccinelli et al., 2008). Citrus fruits are the most important and widely grown non-climacteric fruit crops (Paul et al., 2012). Temperature ranges from 30 to $40{ }^{\circ} \mathrm{C}$ is found to be adequate for tree growth and yield. Citrus fruits are less perishable fruit. The respiration rate which is an important element of the shelf life of fruit is affected by humidity, temperature, movement of air, bruises, and microbial activity (Chhikara et al., 2018).

Citrus sinensis is a very important fruit and export commodity of Pakistan a total production of 2334 thousand tons on an area of 195,000 ha (Swinnen and Squicciarini, 2012; Jabeen et al., 2016). In Pakistan major producing areas are Punjab and Khyber Pakhtunkhwa (Peshawar, Malakand, Dir, Buner, Nowshera and Haripur). In the Khyber Pakhtunkhwa province, the major citrus grown is sweet orange having 32.30 thousand tons per annum production from 4000 hectares (Ghafoor et al., 2016). June 2021 | Volume 34 | Issue 2 | Page 438 
Sweet orange is important for health. It contains a wide range of active ingredients. Which is a rich in vitamin $\mathrm{A}$, vitamin $\mathrm{C}$, flavonoids, acids volatile oils and potassium (Etebu and Nwauzoma, 2014). They are eaten fresh or processed into juice.

During November-December, the fruits are harvested and stored in cold storages. Citrus fruits have more storage life, as they have low rates of respiration and ethylene production (Kader and Arpaia, 2002), but storage at a lower temperature may cause injuries and subsequent higher respiration rate with more changes in biochemistry (Crifò et al., 2011). Postharvest losses of horticulture crops affect both the nutritional status of the population and the economy of the country be controlled through chemical treatment, uses of biological control agents, proper packing and storage facilities, and other post-harvest practices to reduce post-harvest damages (Etebu and Nwauzoma, 2014).

Keeping in view the importance of sweet orangs and postharvest losses, it is essential to evaluate the effect of diverse localities on postharvest quality of sweet orange. Therefore, the current study was conducted to investigate the post-harvest performance of citrus from different localities in Khyber Pakhtunkhwa from the behalf of The Agriculture University of Peshawar.

\section{Materials and Methods}

The sweet orange variety Blood Red were harvested on 15 January 2016 from four different locations i.e. Location-1 (Torwarsak, Buner), Location-2 (Rabat, Lower Dir), Location-3 (Wartair, Malakand) and Location-4 (Palai, Malakand). The initial data was recorded on the day of freshly harvested and after that 12 days interval data were collected up to 48 days in Postharvest Laboratory at Horticulture Department, UAP during the year 2016. The research was performed in Complete Randomized Design (CRD) having three repetitions. During the data analysis, 3 fruits were taken from each treatment for quality attributions.

\section{Physico-chemical analysis}

Titratable acidity (\%): Standard methodology proposed in (Hernández et al., 2006) was applied for determining titratable acidity of fruit sample.

Fruit juice content (\%): Fruit juice content was (Rahman et al., 2017). The post-harvest diseases can its diverse adaptability in climatic conditions and

recorded by the procedure given by (Irshad et al., 2017).

Thickness of the rind ( $\mathrm{mm})$ : Rind thickness from each treatment was measured by using Vernier Caliper and the means were worked out.

Rind weight loss (\%) rind weight loss was recorded using a digital electronic balance. Rind fresh weight was noted in grams. The rind weight loss was determined after 12 days of storage duration with the help of following formula.

Rind weight loss $(\%)=\frac{\text { Weight of fresh rind }(\mathrm{g})-\text { Weight after storage interval }(\mathrm{g})}{\text { weight of fresh rind }(\mathrm{g})} \times 100$

$\mathrm{pH}$ of the fruit juice: Electronic $\mathrm{pH}$ meter was operated for calculating the $\mathrm{pH}$ of sweet orange juice (Lee et al., 2005).

\section{Statistical analysis}

The data recorded were subjected to analysis of variance technique using statistical software STATISTICS 8.1 (Lee et al., 2005).

\section{Results and Discussion}

The Physico-chemical composition of sweet orange juice is given in Table 1 . The statistical analysis showed that mean values of Titratable acidity, Fruit juices content, Rind thickness, Rind weight loss was statistically significant.

Table 1: Physico-chemical composition of sweet orange fruit as influenced by location and storage durations.

\begin{tabular}{|c|c|c|c|c|c|}
\hline $\begin{array}{l}\text { Storage } \\
\text { duration }\end{array}$ & $\begin{array}{l}\text { Titrat- } \\
\text { able } \\
\text { acidity }\end{array}$ & $\begin{array}{l}\text { Fruit } \\
\text { juice } \\
\text { content }\end{array}$ & $\begin{array}{l}\text { Rind } \\
\text { thickness }\end{array}$ & $\begin{array}{l}\text { Rind } \\
\text { weight } \\
\text { loss }\end{array}$ & $\mathrm{pH}$ \\
\hline 0 & $1.97 \mathrm{a}$ & $45.94 \mathrm{a}$ & $0.86 \mathrm{a}$ & $0.00 \mathrm{e}$ & $4.18 \mathrm{e}$ \\
\hline 12 & $1.66 \mathrm{~b}$ & $43.61 \mathrm{~b}$ & $0.83 \mathrm{a}$ & $8.65 \mathrm{~d}$ & $4.29 \mathrm{~d}$ \\
\hline 24 & $1.42 \mathrm{c}$ & $41.58 \mathrm{c}$ & $0.78 \mathrm{~b}$ & $17.52 \mathrm{c}$ & $4.39 \mathrm{c}$ \\
\hline 36 & $1.04 \mathrm{~d}$ & $39.55 \mathrm{~d}$ & $0.72 \mathrm{c}$ & $27.39 \mathrm{~b}$ & $4.48 \mathrm{~b}$ \\
\hline 48 & $0.72 \mathrm{e}$ & $36.56 \mathrm{e}$ & $0.66 \mathrm{~d}$ & $41.42 \mathrm{a}$ & $4.61 \mathrm{a}$ \\
\hline LSD & 0.100 & 0.730 & 0.040 & 4.230 & 0.02 \\
\hline \multicolumn{6}{|l|}{ Locations } \\
\hline $\mathrm{L}_{1}$ & $1.13 \mathrm{~d}$ & $40.23 c$ & $0.85 \mathrm{a}$ & $22.01 \mathrm{a}$ & $4.19 \mathrm{~d}$ \\
\hline $\mathrm{L}_{2}$ & $1.41 \mathrm{~b}$ & $40.78 c$ & $0.87 \mathrm{a}$ & $20.47 \mathrm{a}$ & $4.23 c$ \\
\hline L3 & $1.27 \mathrm{c}$ & $42.93 \mathrm{a}$ & $0.63 \mathrm{c}$ & $15.21 \mathrm{~b}$ & $4.60 \mathrm{a}$ \\
\hline $\mathrm{L}_{4}$ & $1.64 \mathrm{a}$ & $41.85 \mathrm{~b}$ & $0.73 \mathrm{~b}$ & $18.29 \mathrm{ab}$ & $4.55 \mathrm{~b}$ \\
\hline LSD & 0.090 & 0.65 & 0.040 & 3.790 & 0.02 \\
\hline
\end{tabular}

June 2021 | Volume 34 | Issue 2 | Page 439 
The titratable acidity showed a decreasing trend from start-up to 36 days of storage. The maximum titratable acidity was recorded in freshly harvested fruits. While the least titratable acidity was noted after forty-eight days. In case of locations means the highest acidity levels were documented in a different sample of sweet orangs i.e. Palai (Malakand) followed by Rabat (Lower Dir). While minimum titratable acidity $(1.12 \%)$ were observed in $\mathrm{L}_{1}$ (Torwarsak, Buner).

The fruit juice content showed frequently decreasing trend from the start-up to the end of storage. The highest fruit juice content was recorded in fresh fruits at zero storage (45.94\%) as comparatively after 48 days of storage (36.56). Whereas, in locations means the maximum content of juice (42.93\%) was recorded in $\mathrm{L}_{3}$ (Wartair, Malakand) followed by juice content (41.85\%) was observed in $\mathrm{L}_{4}$ (Palai, Malakand). While the lowest juice content $(40.23 \%)$ was recorded in $\mathrm{L}_{1}$ (Torwarsak, Buner).

In case of storage means, the rind thickness of sweet orange showed a decreasing trend from the start to the end of storage. The maximum rind thickness $(0.86$ $\mathrm{mm}$ ) was noted in freshly harvested fruits. While minimum rind thickness $(0.66 \mathrm{~mm})$ were noted at forty-eight days of storage duration. Locations significantly affect the rind thickness of sweet orange fruit. The maximum rind thickness $(0.87 \mathrm{~mm})$ was noted in $\mathrm{L}_{2}$ (Rabat, Lower Dir). While minimum rind thickness $(0.63 \mathrm{~mm})$ was noted in $\mathrm{L}_{3}$ (Wartair, Malakand).

The mean values of storage durations indicate that the rind weight losses increase with the increase in storage durations. The highest rind weight loss percentage $(41.42 \%)$ was noted in fruit stored for forty-eight days. while zero percent $(0.00 \%)$ rind weight loss was recorded in freshly harvested fruit. The mean values of location clarified that the extreme rind weight loss (22.01\%) was noted in $\mathrm{L}_{1}$ (Torwarsak, Buner), which as statistically similar with the rind weight loss (20.47\%) noted in $\mathrm{L}_{2}$ (Rabat, Lower Dir), while the minimum rind weight loss (15.21\%) was observed in $\mathrm{L}_{3}$ (Wartair, Malakand).

In the case of $\mathrm{pH}$, the mean values of fruit juice $\mathrm{pH}$ increase with increase storage durations. The maximum $\mathrm{pH}$ of fruit juice (4.61) was recorded in fruit stored for 48 days, followed by $\mathrm{PH}$ (4.49) of fruit juice stored for thirty-six days. While minimum $\mathrm{pH}$ (4.18) of fruit juice was observed in freshly harvested sweet orange fruit. Likewise, Location mean values significantly affected the $\mathrm{pH}$ of fruit juice. The highest fruit juice $\mathrm{pH}$ (4.60) of location was documented at Location-3 (Wartair, Malakand) by Location-4 (Palai, Malakand). While minimum fruit juice $\mathrm{pH}$ (4.19) was noted in Location-1 (Torwarsak, Buner).

In case of interactive effect (location $\mathrm{x}$ storage durations) for juice content in Figure 1. The fruit juice $\mathrm{pH}$ remained statistically significant. Which showed an increasing trend with storage intervals. The highest fruit juice $\mathrm{pH}$ (4.85) was recorded for the fruit of location-3 (Wartair, Malakand) after 48 days of storage duration, which was closely followed by fruit juice $\mathrm{pH}$ (4.72) after forty-eight days of storage observed in Location-4 (Palai, Malakand). However, the lowest fruit juice $\mathrm{pH}$ (3.96) at zero storage days was noted in location-2 (Rabat, Lower Dir) which was statistically uniform with fruit juice $\mathrm{pH}$ (3.96) at zero storage days was observed in Location-1 (Torwarsak, Buner).

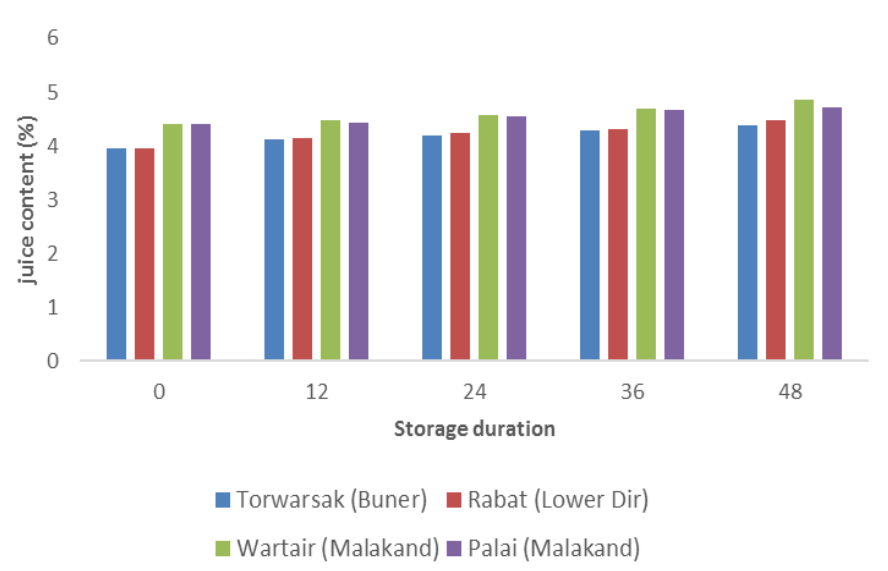

Figure 1: Interactive effect (location storage durations) for juice content.

In case of interactive effect (location $\mathrm{x}$ storage durations) in Figure 2, also significantly affected the juice content of sweet orange fruits. The overall juice content showed a decreasing trend from the start up to the end of storage. The maximum juice content $(46.60 \%)$ was recorded in freshly harvested fruits of Location-4 (Palai, Malakand), which was statistically at par with Location-2 (Rabat, Lower Dir) (46.40\%) at zero storage duration. while less juice content (35.13\%) was noted after 48 days of storage duration in Location-2 (Rabat, Lower Dir).

Titratable acidity: The intermediate metabolites 
of the citric acid cycles are mostly organic acids which are used during the process of respiration and therefore, with increasing storage duration the level of acidity was reduced (Mao et al., 2006; Jalal et al., 2017). The during storage period of fruits, respiration causes consumption of organic acids which lessen the acidity in fruits (Chen et al., 2012).

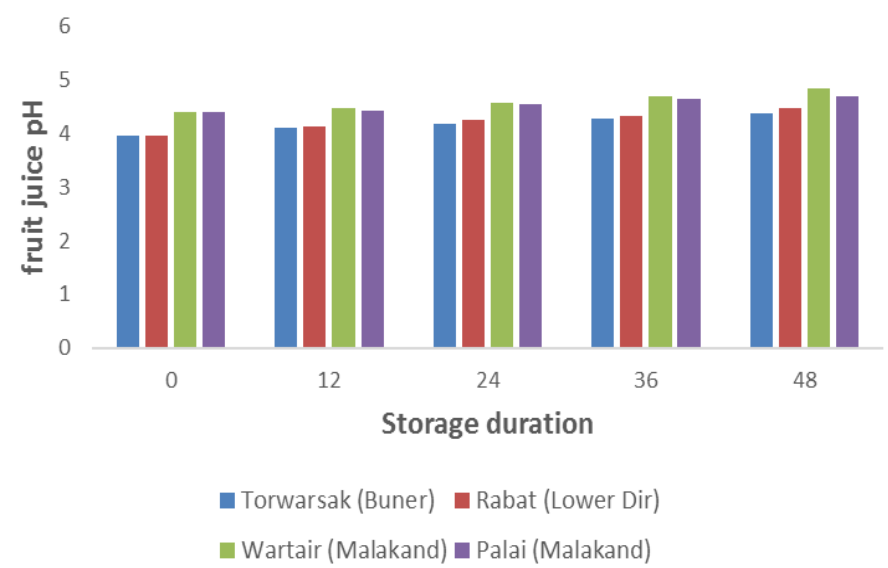

Figure 2: Interactive effect (location $\times$ storage durations) for $\mathrm{pH}$ juice content.

Fruit juice content: It was reported that the different varieties of oranges produced $26-59 \%$ of juice (Lado et al., 2016). During storage, loss of moisture and subsequent decrease in juice content is common in different fruits (Obeed and Harhash, 2006). The moisture loss may be the major reason for decreased content of juice in stored sweet orange fruit. Similarly, delaying harvesting may decrease the uptake of moisture by the fruit reducing the juice content (Pailly et al., 2004). It was reported that the different varieties of oranges produced $26-59 \%$ of juice (Jalal et al., 2017). During storage, loss of moisture and subsequent decrease in juice content is common in different fruits (Tariq et al., 2001). The moisture loss may be the major reason for decreased content of juice in stored sweet orange fruit. Similarly, delaying harvesting may decrease the uptake of moisture by the fruit reducing the juice content (Pailly et al., 2004).

Rind thickness: The maximum rind thickness of sweet orange might be due to the favourable climatic condition of Torwarsak (Buner) and Rabat (Lower Dir). These results are in full accord with (Camarena et al., 2007) who observed that minimum rind thickness is extended with the effect of storage durations. The results are further supported by Cohen et al. (1972) who observed the profound impact of climate on rind thickness.
Rind weight loss: The variation in rind weight loss across different locations might be attributed to a different climatic condition like humidity and temperature. These results are supported by Rickman et al. (2007) who observed that climatic condition had a profound impact on fruit peel weight loss of citrus fruits. These results are also supported by (Camarena et al., 2007). Singh and Reddy (2006) observed reduction in dry matter content of citrus fruits and rind with increasing time of storage.

pH of the fruit juice: all fruits showed an increase in $\mathrm{pH}$ values during storage due to breakup of acids to sugars during respiration (Ball, 1997). Hussein (2014) also stated that during storage the respiration and aging process caused degradation of organic acids and eventually enhanced the $\mathrm{pH}$ and lessened acidity. The increasing trend of fruit juice $\mathrm{pH}$ noted at different storage days was obtained from various treated and untreated fruits (Ahmad et al., 2013). The rising tendency of $\mathrm{pH}$ of the fruit juice was also checked by (Faasema et al., 2011).

\section{Conclusions and Recommendations}

The recorded data obtained from Physico-chemical analysis of different sweet oranges which were taken from various locations in KPK. The statistical analysis showed that the best temperature for sweet oranges during storage with relative humidity (RH) 45-50\%), for one month is $20 \pm 1^{\circ} \mathrm{C}$. Among different storage duration, the fruit holds its quality attributes up to 30 days of storage. The increased in storage duration, titratable acidity, \% juice content, and rind thickness, rind weight, $\mathrm{pH}$ also showed an increasing trend.

\section{Acknowledgments}

The authors would like to thanks the University of Agriculture, Peshawar Khyber Pakhtunkhwa to provided financial support for this research work. The first author, also want to express his deep appreciation Dr. Abdur Rab for all effort in specific time.

\section{Novelty Statement}

The current study was conducted to investigate the post-harvest performance of citrus from different localities in Khyber Pakhtunkhwa from the behalf of The Agriculture University of Peshawar 
Author's Contribution

Aurang Zeb: Worked on research.

Abdur Rab: Supervised the related research

Shujaat Ali: Corresponding Author

Ijaz Hussain, Shah Masaud Khan and Israr Ah-

mad: Helped in analyzed the data, figures drawing, and revision of the manuscript.

Bilal Pervaiz Khan, Shakila Umer and Muhammad

Abbas: Contributed the chemical and materials.

Conflict of interest

The authors have declared no conflict of interest.

\section{References}

Ahmad, S., Z. Singh, A.S. Khan and Z. Iqbal.2013. Pre-harvest application of salicylic acid maintain the rind textural properties and reduce fruit rot and chilling injury of sweet orange during cold storage. Pak. J. Agric. Sci., 50(4): 559-569.

Ball, J.A., 1997. Evaluation of two lipid-based edible coatings for their ability to preserve post harvest quality of green bell peppers. Virginia Tech.

Camarena, F., J. Martínez-Mora and M. Ardid. 2007. Ultrasonic study of the complete dehydration process of orange peel. Postharvest Biol. Technol., 43(1): 115-120. https://doi. org/10.1016/j.postharvbio.2006.07.012

Chen, M., Q.Jiang, X.-R. Yin, Q. Lin, J.-Y. Chen, A.C. Allan, C.-J. Xu and K.-S. Chen. 2012. Effect of hot air treatment on organic acid-and sugar-metabolism in Ponkan (Citrus reticulata) fruit. Sci. Hortic., 147: 118-125. https://doi. org/10.1016/j.scienta.2012.09.011

Chhikara,N.,R.Kour, S.Jaglan,P. Gupta,Y.Gat and A. Panghal. 2018. Citrus medica: Nutritional, phytochemical composition and health benefits. A review. Food Funct., 9(4):1978-1992. https:// doi.org/10.1039/C7FO02035J

Cohen, A., J. Lomas and A. Rassis. 1972. Climatic effects on fruit shape and peel thickness in marsh-seedless grapefruit. J. Am. Soc. Hortic. Sci., 97(6): 768.

Crifò, T., I. Puglisi, G. Petrone, G.R. Recupero and A.R.L. Piero. 2011. Expression analysis in response to low temperature stress in blood oranges: implication of the flavonoid biosynthetic pathway. Gene, 476(1-2): 1-9. https://doi.org/10.1016/j.gene.2011.02.005
Etebu, E. and A. Nwauzoma. 2014. A review on sweet orange (Citrus sinensis L Osbeck): health, diseases and management. Am. J. Res. Commun., 2(2): 33-70.

Faasema, J., J. Abu and J. Alakali. 2011. Effect of packaging and storage condition on the quality of sweet orange (Citrus cinesis). J. Agric. Sci. Tech. Iran, 7(3): 797-804.

Ghafoor, A., T.U. Rehman, A. Munir, M. Ahmad and M.Iqbal.2016. Current status and overview of renewable energy potential in Pakistan for continuous energy sustainability. Renew. Sust. Energ. Rev., 60: 1332-1342. https://doi. org/10.1016/j.rser.2016.03.020

Hernández, Y., M.G. Lobo and M. González. 2006. Determination of vitamin $\mathrm{C}$ in tropical fruits: A comparative evaluation of methods. Food Chem., 96(4): 654-664. https://doi. org/10.1016/j.foodchem.2005.04.012

Hussein, Z., 2014. Perforation-mediated modified atmosphere packaging (PM-MAP) and shelflife of pomegranate fruit arils (cv. ACCO). Stellenbosch: Stellenbosch University.

Irshad, M., A. Murtza, M. Zafar, K.H. Bhatti, A. Rehman and Z. Anwar. 2017. Chitosanimmobilized pectinolytics with novel catalytic features and fruit juice clarification potentialities. Int. J. Biol. Macromol., 104: 242-250. https:// doi.org/10.1016/j.ijbiomac.2017.06.027

Jabeen, T., H.M.I. Arshad, K. Saleem, S. Ali, E. Ullah, S. Naureen and M.M. Babar. 2016. Morphological and biochemical characterization of Xanthomonas axenopodis PV. Citric isolates causing citrus canker disease in Pakistan. PSM Microbiol., 1(1): 10-17.

Jalal, A., S.A.S. Bacha, S. Rani, S.M. Shah, M. Junaid, S. Ali and A. Ahmed. 2017. Quality evaluation and nutritive value of the different mango juices available in the market.

Kader, A.A., 2002. Postharvest technology of horticultural crops. 3311: University of California Agriculture and Natural Resources.

Lado, J., L. Zacarías and M.J. Rodrigo. 2016. Regulation of carotenoid biosynthesis during fruit development. In carotenoids in nature. Springer, Cham. pp. 161-198. https://doi. org/10.1007/978-3-319-39126-7_6

Lee, J., R.W. Durst and R.E. Wrolstad. 2005. Determination of total monomeric anthocyanin pigment content of fruit juices, beverages, natural colorants, and wines by the 
$\mathrm{pH}$ differential method: Collaborative study. J. AOAC Int., 88(5): 1269-1278. https://doi. org/10.1093/jaoac/88.5.1269

Mao, L., F. Que and G. Wang. 2006. Sugar metabolism and involvement of enzymes in sugarcane (Saccharum officinarum L.) stems during storage. Food Chem., 98(2): 338-342. https://doi.org/10.1016/j. foodchem.2005.05.076

Obeed, R. and M. Harhash. 2006. Impact of postharvest treatments on storage life and quality of Mexican Lime. J. Adv. Agric. Res., 11(3): 189-193.

Pailly, O.,G.Tison and A. Amouroux.2004. Harvest time and storage conditions of 'Star Ruby' grapefruit (Citrus paradisi Macf.) for short distance summer consumption. Postharvest Biol. Technol., 34(1): 65-73. https://doi. org/10.1016/j.postharvbio.2004.04.005

Paul, V., R. Pandey and G.C. Srivastava. 2012. The fading distinctions between classical patterns of ripening in climacteric and non-climacteric fruit and the ubiquity of ethylene. An overview. J. Food Sci. Technol., 49(1): 1-21. https://doi. org/10.1007/s13197-011-0293-4

Piccinelli, A.L., M.G. Mesa, D.M. Armenteros, M.A. Alfonso, A.C. Arevalo, L. Campone and L. Rastrelli. 2008. HPLC-PDA-MS

and NMR characterization of C-glycosyl flavones in a hydroalcoholic extract of Citrus aurantifolia leaves with antiplatelet activity. J. Agric. Food Chem., 56(5): 1574-1581. https:// doi.org/10.1021/jf073485k

Rahman,M., E. Bari and S.M.Farin.2017.SAARC Food Bank (SFB): Institutional architecture and issues of operationalisation.

Rickman, J.C., D.M. Barrett and C.M. Bruhn. 2007. Nutritional comparison of fresh, frozen and canned fruits and vegetables. Part 1. Vitamins $\mathrm{C}$ and $\mathrm{B}$ and phenolic compounds. J. Sci. Food Agric., 87(6): 930-944. https://doi. org/10.1002/jsfa.2825

Singh, K.K. and B.S. Reddy. 2006. Post-harvest physico-mechanical properties of orange peel and fruit. J. Food Eng., 73(2):112-120. https:// doi.org/10.1016/j.jfoodeng.2005.01.010

Swinnen, J. and P. Squicciarini. 2012. Mixed messages on prices and food security. Science, 335(6067): 405-406. https://doi.org/10.1126/ science.1210806

Tariq, M.A., F. Tahir, A. Asi and J. Iqbal. 2001. Effect of washing and seal packaging on scuffing damaged citrus fruit quality. Int. J. Agric. Biol., (3): 461-463. 